\title{
Effects of Ovariectomy on Intestinal Alkaline Phosphatase Expression in Rats
}

\author{
Hiroko N Matsumoto, ${ }^{1, *}$ Asako Yamamoto, ${ }^{1}$ Tadahiro Iimura, ${ }^{2}$ \\ Shinichiro OIDA, ${ }^{2}$ Ikuko Ezawa, ${ }^{1}$ Satoshi SASAKI ${ }^{2}$ \\ and Masae GoSEKI-SONE ${ }^{2, * *}$ \\ ${ }^{1}$ Department of Food and Nutrition, Japan Women's University, \\ Bunkyo-ku, Tokyo 112, Japan \\ ${ }^{2}$ Department of Biochemistry, Faculty of Dentistry, Tokyo Medical \\ and Dental University, Bunkyo-ku, Tokyo 113, Japan
}

(Received April 23, 1997)

\begin{abstract}
Summary The aim of this study was to investigate the effects of ovariectomy (OVX) on intestinal alkaline phosphatase (ALP) activity in rats. The calcium $(\mathrm{Ca})$ and phosphorus $(\mathrm{P})$ contents and the mechanical strength of bone were decreased significantly by OVX. Two kinds of mRNAs of rat intestinal ALP (RTIN-1 and RTIN-2) were detected by reverse transcription-polymerase chain reaction (RT-PCR). In OVX rats, the level of RTIN-2 mRNA was lowered significantly, while that of RTIN-1 mRNA did not change. This result was compatible with the results of enzymatic activity. This finding suggests the possibility that OVX affects bone metabolism not only directly but also in an indirect way through an intestinal $\mathrm{Ca}$ and/or P metabolism via regulation of intestinal RTIN-2 ALP expression.

Key Words alkaline phosphatase (ALP), ovariectomy (OVX), reverse transcription-polymerase chain reaction (RT-PCR), intestine, calcium (Ca) metabolism
\end{abstract}

Alkaline phosphatase (ALP, EC 3.1.3.1) hydrolyzes a variety of monophosphate esters into inorganic phosphoric acid and alcohol at a high optimum $\mathrm{pH}(\mathrm{pH}$ 8-10). Studies on the genes of this enzyme revealed that there are four ALP isozymes in the human body: tissue non-specific (liver/bone/kidney) (1), intestinal $(2,3)$, placental (4) and placental-like (5). Based on the studies of hypophosphatasia (6), the tissue non-specific type ALP has been thought to be indispensable for bone mineralization.

* Present address: Division of Applied Mechanics, Institute for Medical and Dental Engineering, Tokyo Medical and Dental University, Chiyoda-ku, Tokyo 101, Japan.

** To whom correspondence should be addressed. 
In rats, ALP is classified into two types: tissue non-specific (liver/bone/kidney/ placenta) and intestinal (7). Two kinds of cDNA clones, RTIN-1 and RTIN-2, for rat intestinal ALP were isolated by Lowe et al ( 8 ) and Strom et al (9), respectively. Their cDNA sequences have $79 \%$ homology at the amino acid level.

The level of serum ALP activity is high in some systemic diseases such as rickets (10), calcium deficiency (11) and diabetes (12). In rats, serum ALP is reported to mainly originate from the intestine (13) and also from bone, especially when the animal is young (14). The high activity of intestinal ALP, which localizes at the brush border of the intestinal epithelial cells, suggests the participation of this enzyme in the transport of nutrients such as inorganic phosphate $(\mathrm{P})$ and calcium (Ca) across the membrane $(15,16)$, but little is known about the physiological function of intestinal ALP.

The increased incidence of fractures accompanying osteoporosis is a serious problem in the aged population. A common type of osteoporosis is the postmenopausal bone loss associated with ovarian hormone deficiency. The balance between bone formation and resorption is regulated by the action of various hormones and growth factors. Therefore, it is important to investigate the effect of ovariectomy (OVX) on various factors related to the bone metabolism. Previously, we reported that OVX decreased osteogenetic activity and tissue non-specific ALP activity in rat bone (17). A decrease in Ca absorption by the intestine in OVX rats has been reported (18). Intestinal ALP seems to have an important role in active metabolism by hydrolyzing phospho-compounds to supply free inorganic phosphate; however, a very small number of reports have been published about the effect of OVX on intestinal ALP. In this study, we attempted to examine the expression of intestinal ALP mRNAs (RTIN-1 and RTIN-2) in OVX rats by reverse transcription-polymerase chain reaction (RT-PCR) analysis.

\section{MATERIALS AND METHODS}

Experimental animals. Twelve-month-old female Wistar rats weighing $300 \mathrm{~g}$ were used for the OVX study. The animals were divided into two groups of 6 each. Rats in one group were bilaterally ovariectomized under ether anesthesia. Those of the control group were sham-operated. The rats were then fed a low $\mathrm{Ca}$ diet (Ca: $0.01 \%$, P: $0.3 \%$, Table 1) for the first 42 days and then switched to a normal $\mathrm{Ca}$ diet (Ca: $0.3 \%$, P: $0.3 \%$ ) for 60 days. The diet and distilled water were given ad libitum to all animals, which were weighed periodically during the study. The animals were fasted overnight and sacrificed by bleeding from the abdominal aorta under anesthesia. In order to examine the effect of OVX on young animals, 6-week-old females of the Sprague-Dawley strain, weighing $140 \mathrm{~g}$, were also studied. They were treated similarly; however, young rats were fed a low $\mathrm{Ca}$ diet for the first 28 days and then switched to a normal $\mathrm{Ca}$ diet for 28 days.

Determination of mechanical bone strength and $C a$ and $P$ contents. The breaking-force of femurs dissected from the animals was determined with a 
Table 1. Composition of the experimental diets (\%).

\begin{tabular}{lcc}
\hline \multicolumn{1}{c}{ Constituents } & $\begin{array}{l}\text { Low Ca diets } \\
0.01 \% \mathrm{Ca} \\
0.3 \% \mathrm{P}\end{array}$ & $\begin{array}{l}\text { Normal Ca diets } \\
0.3 \% \mathrm{Ca} \\
0.3 \% \mathrm{P}\end{array}$ \\
& & 64.1 \\
Glucose monohydrate & 18.0 & 18.0 \\
Casein (vitamin-free) & 10.0 & 10.0 \\
Cottonseed oil & 3.0 & 3.0 \\
Roughage & 2.0 & 2.0 \\
Ca- and P-free salt mixture & 1.39 & 1.03 \\
Equimolar mixture of $\mathrm{KH}_{2} \mathrm{PO}_{4}$ and $\mathrm{K}_{2} \mathrm{HPO}_{4}$ & 0.005 & 0.74 \\
CaCO & 0.2 & 0.2 \\
Cystine & 0.1 & 0.1 \\
Water-soluble vitamin mixture & $\mathrm{c}$ & 0.2 \\
Fat-soluble vitamin mixture & 0.2 & 0.2 \\
Choline chloride & & \\
\end{tabular}

${ }^{\mathrm{a}} \mathrm{Ca}$ - and P-free salt mixture (\%): $\mathrm{KCl}, 57.7 ; \mathrm{NaCl}, 20.9 ; \mathrm{MgSO}_{4}, 17.9 ; \mathrm{FeSO}_{4} \cdot 7 \mathrm{H}_{2} \mathrm{O}$, 3.22; $\mathrm{CuSO}_{4} \cdot 5 \mathrm{H}_{2} \mathrm{O}, 0.078 ; \mathrm{CoCl}_{2} \cdot 6 \mathrm{H}_{2} \mathrm{O}, 0.004 ; \mathrm{KI}, 0.01 ; \mathrm{MnSO}_{4} \cdot 5 \mathrm{H}_{2} \mathrm{O}, 0.06$; $\mathrm{ZnSO}_{4} \cdot 7 \mathrm{H}_{2} \mathrm{O}, 0.44$; and $\left(\mathrm{NH}_{4}\right)_{6} \mathrm{Mo}_{7} \mathrm{O}_{24} \cdot 4 \mathrm{H}_{2} \mathrm{O}, 0.005$.

${ }^{\mathrm{b}}$ The water-soluble vitamin mixture (\%): thiamine, 0.5 ; riboflavin, 0.5 ; pyridoxine, 0.5 ; calcium pantothenate, 2.8; nicotinamide, 2.0; inositol, 20.0; folic acid, 0.02; vitamin $\mathbf{B}_{12}$, 0.5 ; biotin, 0.01 ; and glucose monohydrate, 73.7.

${ }^{c}$ The rats received a supplement of the following fat-soluble vitamins in cottonseed oil three times a week: $\beta$-carotene, $70 \mu \mathrm{g} ; 2$-methyl-1,4-naphthoquinone, $105 \mu \mathrm{g}$; tocopherol, $875 \mu \mathrm{g}$; and vitamin $\mathrm{D}_{3}, 515 \mathrm{IU}$.

Dynagraph (DYN-1255, Iio) (19). The femurs were dried to constant weight and extracted with $1 \mathrm{~N}$ nitric acid for $\mathrm{Ca}$ and $\mathrm{P}$ analysis. Ca content was measured with an atomic absorption spectrophotometer (type AA-640-12, Shimadzu) and P content by Fiske-Subbarow's method (20).

Preparation and measurement of intestinal enzyme. Rat duodenum segments were removed immediately after sacrifice, freed from adhering tissue and rinsed with ice-cold saline. The segments were slit open longitudinally, and the mucosa was scraped with a piece of slide glass after rinsing and stored at $-80^{\circ} \mathrm{C}$ prior to use. The sample was homogenized with $10 \mathrm{~mm}$ Tris-buffered saline containing $1 \%$ Triton X-100 using a Teflon homogenizer. The supernatant of centrifugation at $16,000 \times g$ for $15 \mathrm{~min}$ was used for the enzyme assay. ALP activity was measured with $10 \mathrm{~mm} p$-nitro-phenyl phosphate as the substrate in $100 \mathrm{~mm}$ 2-amino-2-methyl1,3-propanediol- $\mathrm{HCl}$ buffer $\left(\mathrm{pH} 10.0\right.$ ) containing $5 \mathrm{mM} \mathrm{MgCl}_{2}$. Absorption at $420 \mathrm{~nm}$ was measured after 10 -min incubation at $37^{\circ} \mathrm{C}$. Sucrase and trehalase activities were assayed by the Dahlqvist method (21).

$R N A$ isolation and $R T-P C R$. Rat intestinal mucosa was scraped from the ileum, and the samples from the animals of one group were collected into one lot. Total RNA was extracted by the guanidium-cesium chloride density centrifugation 
method (22). Single-strand cDNA was prepared from $1 \mu \mathrm{g}$ of total RNA using the SuperScript pre-amplification system (Gibco BRL) and was used as a template for PCR. Two sets of specific primers were designed for the rat intestinal ALP sequences (23). For the RTIN-1 nucleotide sequence (8), PCR primers AL7 (1082-1102) and AL8 (1310-1330) were used. For the RTIN-2 nucleotide sequence (9), AL9 (1455-1475) and AL10 (1652-1672) were used. Amplification was performed by a 2-step incubation using a Perkin-Elmer/Cetus DNA thermal cycler (Type 9600) at $94^{\circ} \mathrm{C}(1 \mathrm{~min}), 50^{\circ} \mathrm{C}(1 \mathrm{~min}), 72^{\circ} \mathrm{C}(1 \mathrm{~min})$ for 5 cycles and at $94^{\circ} \mathrm{C}(30 \mathrm{~s}), 55^{\circ} \mathrm{C}(30 \mathrm{~s})$ and $72^{\circ} \mathrm{C}(30 \mathrm{~s})$ for 25 cycles. The PCR products were electrophoresed on a $10 \%$ SDS-polyacrylamide gel.

Biochemical analysis of serum. Serum was separated by centrifugation and stored at $-80^{\circ} \mathrm{C}$ prior to use. Ca concentration was measured by the OCPC method (24) and the P content by Machida's method (25). Protein was measured by the Lowry method (26).

Serum ALP activity was measured by the method of Bessey-Lowry (27). The inhibition experiment was carried out with L-homoarginine (L-HA, 0-10 mM), levamisole (LEV, 0-1 mM) and L-phenylalanine (L-PA, 0-20 mM). The inhibitor concentration in $\mathrm{mM}$ required for reduction of ALP activity to $50 \%$ was determined. In the thermostability test, the enzyme sample was pre-treated at $56^{\circ} \mathrm{C}$ or $60^{\circ} \mathrm{C}$ and the activity was measured. The time (in minutes) required for reduction of ALP activity to $50 \%$ was determined. In comparison with tissue isozymes, extracts from rat kidney, intestine, liver and calvarium were prepared. The tissue was homogenized in an equal volume of $10 \mathrm{~mm}$ Tris-buffered saline containing $1 \%$ Triton $\mathrm{X}-100$. The homogenate was treated with $50 \% n$-butanol, and the aqueous phase obtained was mixed with an equal volume of acetone. The precipitate was dried and used as a crude ALP preparation.

Polyacrylamide gel electrophoresis. Gradient gel electrophoresis (4-20\%) was carried out as described previously (28). After electrophoresis, ALP isozymes separated in the gel were stained by the coupling method of $\beta$-naphthyl-phosphoric acid monosodium salt with Fast Violet B salt (29).

Statistics. The data were expressed as mean \pm SD. Statistical significances were evaluated by Student's $t$-test. The difference was judged to be significant when $p$ values were less than 0.05 .

\section{RESULTS}

\section{Effect of OVX on 12-month-old rat bone, serum and intestine}

OVX caused a significant decrease in femoral bone strength as compared to the control group (Table 2). Also, bone $\mathrm{Ca}$ and $\mathrm{P}$ contents decreased significantly after OVX. However, there was no change in the serum $\mathrm{Ca}$ and $\mathrm{P}$ levels of the OVX and sham-operated rats. These data indicate that osteoporotic changes developed in OVX rats under our experimental conditions. No differences were observed in body weight gain or food efficiency between 12-month-old OVX and 
Intestinal ALP Expression in OVX Rat

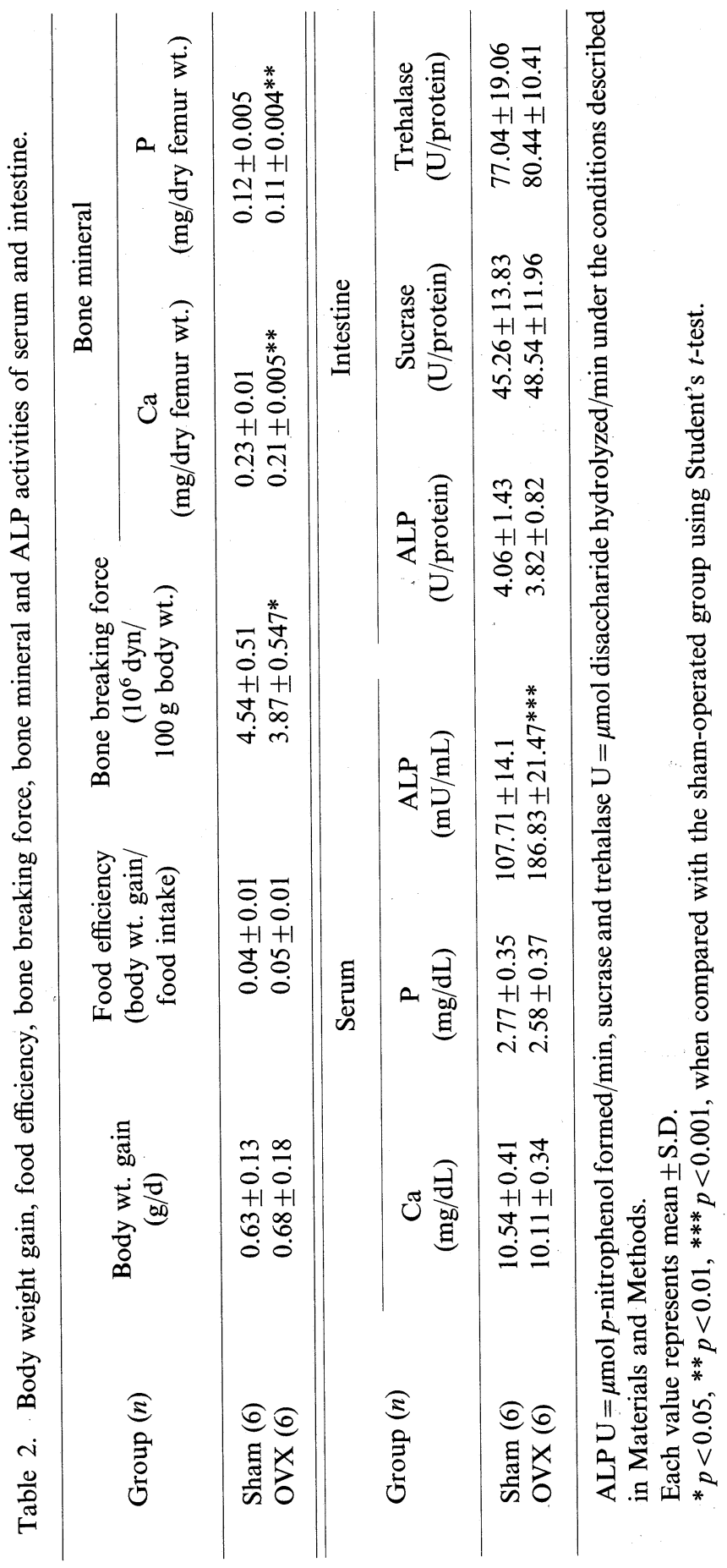


sham-operated rats. The intestinal ALP activity tended to decrease in OVX rats but with no statistical significance (Table 2). Sucrase and trehalase activities did not change as a result of OVX. Serum ALP activity showed a tendency to increase due to OVX $(p<0.001)$.

\section{Serum ALP isozymes}

The results of inhibition and thermostability experiments on 12-month-old rat serum and tissue ALP activities are summarized in Table 3. Among the three inhibitors tested, L-homoarginine and levamisole did not inhibit serum or intestinal ALP activity, but L-phenylalanine inhibited both serum and intestinal ALP. In addition, the thermostability pattern of serum ALP seemed to be similar to that of liver ALP. These data suggest that serum ALP is a mixture of tissue isozymes.

Further identification of the enzyme types by polyacrylamide gradient gel electrophoresis was carried out on young rats (Fig. 1). There were two bands (indicated by arrows "a" and "b") in the rat serum. The upper band (a) is an isozyme corresponding to the bone type ALP which lost its activity as a result of the heat treatment. The activity of this isozyme in serum seemed to increase after OVX (Fig. 1, lane 6).

Table 3. Inhibitory pattern of ALPs in tissues and serum.

\begin{tabular}{|c|c|c|c|c|c|}
\hline \multirow{2}{*}{ Inhibitor } & \multicolumn{5}{|c|}{ Rat tissues } \\
\hline & Calvarium & Liver & Kidney & Intestine & Serum \\
\hline \multicolumn{6}{|l|}{ L-Homoarginine } \\
\hline Activity $\%$ at $10 \mathrm{~mm}(\%)$ & 17 & 63 & 17 & 102 & 105 \\
\hline $\begin{array}{l}\text { Concentration for } 50 \% \\
\text { inhibition (mM) }\end{array}$ & 1.47 & $10 \ll$ & 1.63 & $10 \ll$ & $10 \ll$ \\
\hline \multicolumn{6}{|l|}{ Levamisol } \\
\hline Activity $\%$ at $10 \mathrm{mM}(\%)$ & 2 & 58 & 5 & 100 & 100 \\
\hline $\begin{array}{l}\text { Concentration for } 50 \% \\
\text { inhibition (mM) }\end{array}$ & 0.02 & $1 \ll$ & 0.03 & $1 \ll$ & $1 \ll$ \\
\hline \multicolumn{6}{|l|}{ L-Phenylalanine } \\
\hline Activity $\%$ at $10 \mathrm{~mm}(\%)$ & 83 & 44 & 57 & 21 & 42 \\
\hline $\begin{array}{l}\text { Concentration for } 50 \% \\
\text { inhibition (mM) }\end{array}$ & $20 \ll$ & 14.7 & $20 \ll$ & 3.2 & 15.0 \\
\hline \multicolumn{6}{|l|}{$56^{\circ} \mathrm{C}$} \\
\hline Activity $\%$ at $30 \mathrm{~min}(\%)$ & 8 & 12 & 1 & 60 & 12 \\
\hline Time for $50 \%$ inhibition (min) & 2.36 & 4.39 & 2.84 & $30 \ll$ & 5.20 \\
\hline \multicolumn{6}{|l|}{$60^{\circ} \mathrm{C}$} \\
\hline Activity $\%$ at $30 \mathrm{~min}(\%)$ & 14 & 7 & 1 & 40 & 10 \\
\hline Time for $50 \%$ inhibition (min) & 0.99 & 2.03 & 0.90 & 8.70 & 2.30 \\
\hline
\end{tabular}




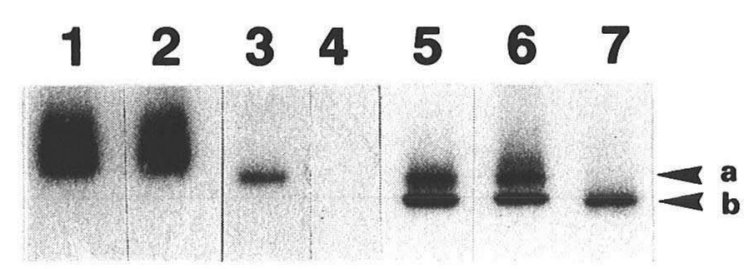

Fig. 1. Rat serum and tissue ALP isozymes separated by polyacrylamide gel electrophoresis. Samples were electrophoresed on 4-20\% gradient polyacrylamide gel. Serum samples of $15 \mu \mathrm{L}$ were applied onto one lane. ALP activity was stained with $\beta$-naphthyl-phosphoric acid monosodium salt, Fast Violet B salt. Lanes 1, 2, intestine; 3, 4, calvarium; 5 , serum of sham-operated young rat; 6,7 , serum of OVX young rat. Lanes 2,4 and 7 were pretreated at $56^{\circ} \mathrm{C}$ for $10 \mathrm{~min}$.

\section{RT-PCR analysis of intestinal ALP mRNA expression}

Intestinal ALP mRNA expression was examined by RT-PCR analysis. A 249 bp product was detected by the primer set of AL7 and AL8 for RTIN-1, which was at a similar level in OVX and sham-operated rats (Fig. 2A, lanes 1, 2). On the other hand, the $218 \mathrm{bp}$ band detected by the primer set of AL9 and AL10 for RTIN-2 decreased after OVX (Fig. 2A, lanes 3, 4). Because glyceraldehydephosphate dehydrogenase (GAPDH) bands did not change due to OVX (Fig. 2B), the decrease in RTIN-2 mRNA expression is specific for OVX. The same result was obtained in the experiment using young rats. These data coincide with the finding that the enzymatic activity of intestinal ALP tended to decrease in OVX rats. One of the two ALP messages, RTIN-2 expression, was suppressed by OVX, so that the total ALP activity did not dramatically decrease.

\section{DISCUSSION}

OVX significantly reduced the mechanical strength and the $\mathrm{Ca}$ and $\mathrm{P}$ contents of the femur in rats. Under the experimental conditions presented here, serum $\mathrm{Ca}$ and $\mathrm{P}$ showed no change. This may be because Ca-regulating hormones maintained serum $\mathrm{Ca}$ and $\mathrm{P}$ at normal levels even in the absence of estrogen. It was evident that OVX produced osteoporotic changes probably because of the altered bone and mineral metabolism in rats. Increase in body weight as a result of OVX has been reported in a previous paper (30). In our experiment, no differences were observed in body weight or food efficiency between OVX and sham-operated old (12-month-old) rats, although there was some body weight gain in young (6-weekold) OVX rats $(2.05 \pm 0.18 \mathrm{~g} / \mathrm{d})$ as compared to the sham-operated rats $(1.39 \pm$ $0.11 \mathrm{~g} / \mathrm{d}$ ). Intestinal ALP activity tended to decrease after OVX. There are two forms of ALP in the intestine: one is a membrane-bound type anchored to phosphatidylinositol and the other is a soluble type released from the membrane (31). In this study, the total activity of two types of ALP was determined by extraction with a surfactant, $1 \%$ Triton X-100 (32). Sucrase and trehalase are 
A

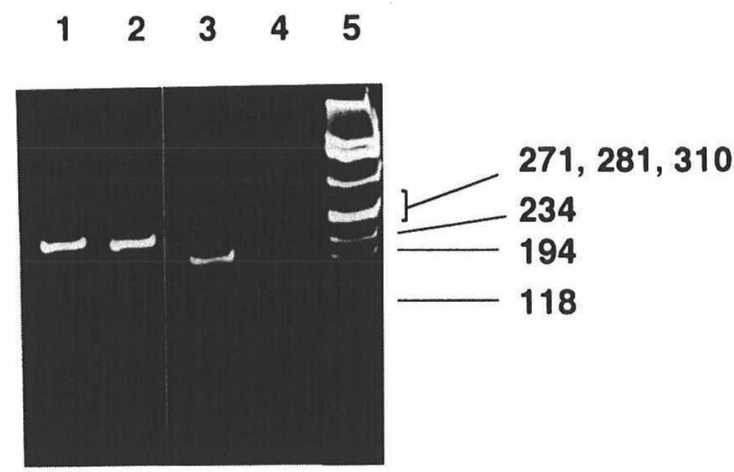

B

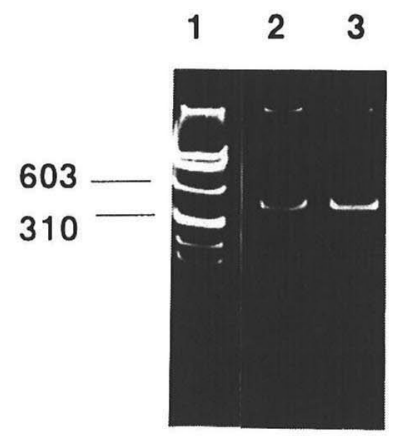

Fig. 2. Detection of RTIN-1 and RTIN-2 ALP mRNA expression in rat intestine by RT-PCR. Samples were prepared from 12-month-old rat intestine and applied to PCR as described in Materials and Methods. PCR products were electrophoresed on a $10 \%$ polyacrylamide gel. A: PCR products generated by the primer set for RTIN-1 from sham-operated (lane 1) and OVX (lane 2) rat intestine, and generated by the primer set for RTIN-2 from sham-operated (lane 3), OVX (lane 4) rat intestine and molecular size marker phi-X HaeIII digest (lane 5). B: PCR products generated by the primer set for GAPDH from sham-operated (lane 2), OVX (lane 3) and molecular size marker phi-X HaeIII digest (lane 1).

digestive enzymes which are also anchored to the membrane, like ALP (33). Their enzymatic activities showed no change after OVX. Therefore, the decrease in activity caused by OVX is thought to be specific to intestinal ALP. Two types of mRNAs for intestinal ALP were examined by RT-PCR analysis. We confirmed the nucleotide sequences of the PCR products for RTIN-1 mRNA and RTIN-2 mRNA described previously (23). One of the transcripts, RTIN-2 mRNA, was found to be reduced 
by OVX. Therefore, the decrease in intestinal ALP activity caused by OVX might result from the suppression of RTIN-2 mRNA transcription.

There is a report showing the elevation of intestinal ALP mRNA by $1 \alpha, 25(\mathrm{OH})_{2} \mathrm{D}_{3}$ treatment (34), and Strom et al (9) found that expression of RTIN-2 mRNA increased with $1 \alpha, 25(\mathrm{OH})_{2} \mathrm{D}_{3}$ administration. We also found that expression of RTIN-2 mRNA in the liver was enhanced by feeding fat (23). These findings support the possibility that the level of RTIN-2 is more variable than that of RTIN-1 in response to bioactive factors.

A decrease in $\mathrm{Ca}$ absorption by the intestine in OVX rats has been reported (18), and the possibility was suggested that $\mathrm{Ca}$ malabsorption may be induced by blocking $1 \alpha, 25(\mathrm{OH})_{2} \mathrm{D}_{3}$ action because there was a study (35) indicating that the intestinal $1 \alpha, 25(\mathrm{OH})_{2} \mathrm{D}_{3}$ receptor number decreased with estrogen deficiency. It is also believed that the decrease in RTIN-2 mRNA expression caused by OVX may be the result of the decrease in $1 \alpha, 25(\mathrm{OH})_{2} \mathrm{D}_{3}$ receptor expression. The active form of vitamin D enhances both intestinal ALP activity and the absorption rate of $\mathrm{Ca}$ and/or $\mathrm{P}$ in ligated intestine (36). However, we do not know whether there was a direct involvement of vitamin D in decreasing the ALP mRNA level in this study.

In contrast to the intestinal ALP, serum ALP activity was rather high in OVX rats in response to estrogen deficiency. Several studies suggest that rat serum ALP originates mainly from the intestine (13) and partly from bone, especially in young rats (14). The presence of two ALP bands was shown in the serum by electrophoresis (Fig. 1). The enzymatic activity of the upper band (band "a"), with the same mobility as that of the enzyme extracted from bone, was lost after heat treatment. In our previous study, serum ALP activity in the OVX group was higher than that in the sham-operated group, and heat-stable type ALP was not affected by OVX (17). Elevated serum ALP activity in OVX rats may be due to an increase in bonederived ALP but not in the intestine-derived enzyme. In the case of human osteoporosis, there is a report on an increase in tissue non-specific type ALP activity (37).

It has been thought that OVX causes experimental osteoporosis by disturbed bone formation or enhanced bone resorption due to lack of estrogen. In addition, this study revealed that malabsorption mediated by the suppression of RTIN-2 ALP expression may occur in OVX rats. Therefore, there is a possibility that the $\mathrm{Ca}$ and $\mathrm{P}$ supply necessary for bone formation is not sufficient. The data presented here suggests that the nutritional effects of OVX on the intestine must be taken into account because its expression is also regulated by $1 \alpha, 25(\mathrm{OH})_{2} \mathrm{D}_{3}, \mathrm{RTIN}-2$ is an important enzyme which may be involved in bone metabolism. Further study on the mechanism of estrogen action on RTIN-2 expression will be necessary inthe future.

We thank Dr. Masato Tamura (Medical Research Institute, Tokyo Medical and Dental University) and Dr. Akira Ishizaki (1st Department of Oral Surgery, Tokyo Medical and Dental University) for their advice on the experimental techniques. This study was supported in part by the Japan Society for the Promotion of Science, "Research for the Future" Program, JSPS-RFTF 96 I 00205. 


\section{REFERENCES}

1) Weiss MJ, Ray K, Henthorn PS, Lamb B, Kadesch T. 1988. Structure of the human liver/bone/kidney alkaline phosphatase gene. J Biol Chem 263: 12002-12010.

2) Henthorn PS, Raducha M, Kadesch T, Weiss MJ, Harris H. 1988. Sequence and characterization of the human intestinal alkaline phosphatase gene. J Biol Chem 263: 12011-12019.

3) Millan JL. 1987. Promoter structure of the human intestinal alkaline phosphatase. Nucleic Acids Res 15: 10599.

4) Knoll BJ, Rothblum KN, Longley M. 1988. Nucleotide sequence of the human placental alkaline phosphatase gene. J Biol Chem 263: 12020-12027.

5) Shen LP, Liu H, Kan YW, Kam W. 1988. 5' Nucleotide sequence of a putative human placental alkaline phosphatase-like gene. Nucleic Acids Res 16: 5694.

6) Whyte MP. 1995. Hypophosphatasia. In: The Metabolic and Molecular Basis of Inherited Disease (Scriver CR, Beaudet AL, Sly WS, Valle D, eds), p 4095-4111. McGraw-Hill, New York.

7) Goldstein DJ, Rogers CE, Harris H. 1980. Expression of alkaline phosphatase loci in mammalian tissues. Proc Natl Acad Sci USA 77: 2857-2860.

8) Lowe M, Strauss AW, Alpers R, Seetharam S, Alpers DH. 1990. Molecular cloning and expression of a cDNA encoding the membrane-associated rat intestinal alkaline phosphatase. Biochem Biophys Acta 1037: 170-177.

9) Strom M, Krisinger J, DeLuca HF. 1991. Isolation of a mRNA that encodes a putative intestinal alkaline phosphatase regulated by 1,25-dihydroxy vitamin D-3. Biochem Biophys Acta 1090: 299-304.

10) Zerwekh JE, Pak CYC. 1979. Vitamin D-dependent rickets: A case of target organ resistance to $1 \alpha, 25$-dihydroxy vitamin $\mathrm{D}$ and impaired vitamin D-25-hydroxylase. In: Vitamin D-Basic Research and Its Clinical Application (Norman AW, Schaefer K, Hernath Dv, Grigoleit HG, Coburn JW, DeLuca HF, Mawer EB, Suda T, eds), p 1139-1149. Walter de Gruyter, Berlin-New York.

11) Tanimoto H, Law KHW, Nishimoto SK, Wergedal JE, Baylimk DJ. 1991. Evaluation of the usefulness of serum phosphatase and osteocalcin as serum markers in a calcium depletion-repletion rat model. Calcif Tissue Int 48: 101-110.

12) Unakami S, Komoda T, Sakagishi Y. 1990. Translocation of intestinal alkaline phosphatase in streptozotocin-induced diabetic rats. Int $J$ Biochem 22: 1325-1331.

13) Madsen NB, Tuba J. 1952. On the source of the alkaline phosphatase in rat serum. $J$ Biol Chem 195: 741-750.

14) Unakami S, Hirata M, Ichinohe K, Tanimoto Y, Iizuka H. 1989. Separation and quantification of serum alkaline phosphatase isozymes in the rat by affinity electrophoresis. Exp Anim 38: 85-88.

15) Hirano K, Iiizumi Y, Mori Y, Toyoshi K, Sugiura M, Iino S. 1985. Role of alkaline phosphatase in phosphate uptake into brush border membrane vesicles from human intestine mucosa. J Biochem 97: 1461-1466.

16) Roubati C, Portman P. 1988. Relation between intestinal alkaline phosphatase activity and brush border membrane transport of inorganic phosphate, D-glucose-6-phosphate. Pflugers Arch 412: 482-490.

17) Goseki SM, Omi N, Yamamoto A, Oida S, Ezawa I, Sasaki S. 1996. Ovariectomy decreases osteogenetic activity in rat bone. J Nutr Sci Vitaminol 42: 55-67.

18) Kalu DN, Liu CC, Hardin RR, Hollis BW. 1989. The aged rat model of ovarian 
hormone deficiency bone loss. Endocrinology 124: 7-16.

19) Ezawa I, Okada R, Nozaki Y, Ogata E. 1979. Breaking-properties and ash contents of the femur of growing rat fed a low calcium diet. Nippon Eiyo Shokuryo Gakkaishi ( $J$ Jpn Soc Food Nutr) 32: 329-335.

20) Fiske CH, Subbarow Y. 1925. The colorimetric determination of phosphorus. J Biol Chem 66: 375-400.

21) Dahlqvist A. 1984. $\alpha$-Glucosidases (Disaccharidases). In: Methods of Enzymatic Analysis (Bergmeyer HU, ed), p. 208-217. Verlag Chemie, Weinheim.

22) Chirgwin JM, Przybyla AE, MacDonald RJ, Rutter WJ. 1979. Isolation of biologically active ribonucleic acid from sources enriched in ribonuclease. Biochemistry 18: 5294-5299.

23) Goseki-Sone $M$, Oida S, Iimura T, Yamamoto A, Matsumoto NH, Omi N, Takeda K, Maruoka Y, Ezawa I, Sasaki S. 1996. Expression of mRNA encoding intestinal type alkaline phosphatase in rat liver and its increase by fat-feeding. LIVER 16: 358364.

24) Harold V, Connerty MD, Anglis RBBS. 1966. Determination of calcium by means of ortho-cresolphthaline complexon. Am J Clin Pathol 45: 290-296.

25) Machida Y, Nakanishi T. 1982. Utilization of bacterial xanthine oxidase for inorganic phosphorus determination. Agric Biol Chem 46: 807-808.

26) Lowry OH, Rosebrough NJ, Farr AL, Randall RJ. 1951. Protein measurement with the folin phenol reagent. $J$ Biol Chem 193: 265-274.

27) Bessey OT, Lowry OH, Brock MJ. 1946. A method for the rapid determination of alkaline phosphatase with five cubic millimeters of serum. J Biol Chem 164: 321-329.

28) Goseki (Sone) M, Omi N, Oida S, Ezawa I, Sasaki S. 1995. Voluntary exercise increases osteogenetic activity in rat bones. Bull Tokyo Med Dent Univ 42: 1-8.

29) Kurahashi Y, Yoshiki S. 1972. Electron microscopic localization of alkaline phosphatase in the enamel organ of the young rat. Archs Oral Biol 17: 155-163.

30) Aitken JM, Armstrong E, Anderson JB. 1972. Osteoporosis after oophorectomy in the mature female rat and the effect of estrogen and/or progesteron replacement therapy in its prevention. $J$ Endocrinol 55: 79-87.

31) Yedlin ST, Young GP, Seetharam S, Alpers DH. 1987. Characterization and comparison of soluble and membranous forms of intestinal alkaline phosphatase from the suckling rat intestine. $J$ Biol Chem 256: 5620-5626.

32) Coutinho HB, Katchburian E, Pears AGE. 1966. Effects of Triton-X-100 upon the mobility of esterase and alkaline phosphatases in disc electrophoresis. $J$ Clin Pathol 19: 617 .

33) Semenza G. 1985. Anchoring and biosynthesis of a major intrinsic plasma membrane protein: The sucrase-isomaltase complex of the small-intestinal brush border. In: The Enzymes of Biological Membranes (Martonosi AN, ed), p 331-348. Plenum Press, New York.

34) Eliakim R, Seetharam S, Tietze CC, Alpers DH. 1990. Differential regulation of mRNAs encoding for rat intestinal alkaline phosphatase. Am J Physiol 259: G93-98.

35) Chan SDH, Chiu DKH, Atkins D. 1984. Oophorectomy leads to a selective decrease in 1,25-dihydroxycholecalcifeal receptors in rat jejunal villous cells. Clin Sci 66: 745.

36) Yeh JK, Aloia JF. 1986. Intestinal calcium and phosphate transport and intestinal alkaline phosphatase. Bone and Mineral 1: 297-306.

37) Nishizawa Y, Morii H. 1990. Biochemical for bone turnover in osteoporotic patients. The Bone 4: 31-37. 